\title{
BRPKM
}

Buletin Riset Psikologi dan Kesehatan Mental

http://e-journal.unair.ac.id/index.php/BRPKM

e-ISSN: 2776-1851

ARTIKEL PENELITIAN

\section{Pengaruh Fear of COVID-19 terhadap Burnout dengan Variabel Mediator Resiliensi pada Tenaga Kesehatan}

\author{
FIKRI HADYAN KUSUMA \& HERISON PANDAPOTAN PURBA* \\ Fakultas Psikologi Universitas Airlangga
}

\begin{abstract}
ABSTRAK
Penelitian ini bertujuan untuk mengetahui apakah ada efek mediasi dari resiliensi terhadap pengaruh fear of COVID-19 terhadap burnout. Hipotesis penelitian ini adalah (1) Tidak terdapat pengaruh fear of COVID-19 terhadap burnout dengan mediasi resiliensi pada tenaga kesehatan; (2) Terdapat pengaruh fear of COVID-19 terhadap burnout dengan mediasi resiliensi pada tenaga kesehatan. Metode penelitian ini menggunakan survei kuantitatif terhadap tenaga kesehatan. Pengumpulan data dilakukan dengan menggunakan kuesioner daring. Data dianalisis menggunakan analisis mediasi sederhana. Hasil penelitian menunjukkan terdapat efek mediasi parsial sebesar 34.5\% dari resiliensi terhadap pengaruh fear of COVID-19 kepada burnout. Terdapat korelasi positif dan signifikan antara fear of COVID-19 terhadap burnout, korelasi negatif dan signifikan antara fear of COVID-19 terhadap resiliensi, dan korelasi negatif dan signifikan antara resiliensi terhadap burnout, hal ini menunjukkan bahwa resiliensi terbukti memediasi fear of COVID-19 dan Burnout.
\end{abstract}

Kata kunci: burnout, fear of covid-19, resiliensi, tenaga kesehatan

\begin{abstract}
This study aims to determine whether there is a mediating effect of resilience on the effect of fear of COVID-19 on burnout. The hypotheses of this study are (1) There is no effect of fear of COVID-19 on burnout by mediating resilience to health workers; (2) There is an effect of fear of COVID-19 on burnout by mediating resilience to health workers. This research method uses a quantitative survey of health workers. The data was collected using an online questionnaire. Data were analyzed using simple mediation analysis. The results showed that there was a partial mediation effect of $34.5 \%$ of the resilience on the effect of fear of COVID-19 on burnout. There is a positive and significant correlation between the fear of COVID-19 and burnout, a negative and significant correlation between the fear of COVID-19 and resilience, and a negative and significant correlation between resilience to burnout, this shows that resilience is proven to mediate the fear of COVID-19 and Burnout.
\end{abstract}

Keywords: burnout, fear of covid-19, health workers, resilience

Buletin Penelitian Psikologi dan Kesehatan Mental (BRPKM), 2021, Vol. 1(1), 585-594

*Alamat korespondensi: Fakultas Psikologi Universitas Airlangga, Kampus B Universitas Airlangga Jalan Airlangga 4-6 Surabaya 60286. Surel: herison.purba@psikologi.unair.ac.id 


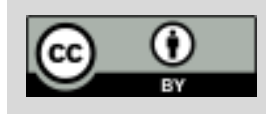

Naskah ini merupakan naskah dengan akses terbuka dibawah ketentuan the Creative Common Attribution License (CC-BY-4.0) (http://creativecommons.org/licenses/by/4.0), sehingga penggunaan, distribusi, reproduksi dalam media apapun atas artikel ini tidak dibatasi, selama sumber aslinya disitir dengan baik.

\section{PEN D A H U L U A N}

COVID-19 adalah sebuah penyakit yang menyerang kesehatan masyarakat global. Sekitar November 2019 penyakit seperti pneumonia muncul di Wuhan, Cina, yang pada akhirnya oleh organisasi kesehatan dunia atau WHO menyebutnya dengan penyakit Coronavirus 2019 atau COVID-19. Hanya dalam beberapa bulan saja, COVID-19 telah menyebabkan kerusakan yang signifikan pada kesehatan masyarakat, dan juga menyebabkan permasalahan finansial di banyak negara (Labrague \& de los Santos, 2020). Sedangkan untuk Indonesia sendiri hingga 11 Februari 2021 sudah tercatat 1,191,990 kasus, dengan 993,117 orang yang sudah sembuh, dan 32,381 yang meninggal. Persebaran kasusnya terjadi paling banyak berada di DKI Jakarta dengan 303,715 kasus, disusul oleh Jawa Barat 170,642 kasus, Jawa Tengah 138,547 kasus, dan Jawa Timur dengan 119,479 kasus, di provinsi setelahnya masing-masing provinsi menyumbang tidak lebih dari 100,000 kasus (COVID-19, 2021).

Dengan munculnya COVID-19, dapat memicu munculnya beragam permasalahan terkait kesehatan mental pada masyarakat, atau memperburuk kesehatan fisik seseorang. Walaupun pengalaman akan permasalahan terkait kesehatan mental bukanlah hal yang dapat dihindari oleh manusia dalam hidupnya, ini dapat menjadi lebih buruk lagi terutama pada para tenaga kesehatan yang selama pandemi mereka berada di depan berhadapan dengan COVID-19. Hal ini dapat memengaruhi kehidupan mereka, dan membutuhkan promosi kesehatan mental mereka (Yıldırım, Arslan, \& Özaslan, 2020). Tenaga kesehatan profesional menghadapi banyak hal tidak terduga terutama beragam reaksi stres. Karena bekerja secara dekat untuk membantu mereka yang terinfeksi COVID-19, tenaga kesehatan memiliki risiko yang lebih besar untuk mengembangkan gejala-gejala permasalahan psikologis termasuk kecemasan, panik, atau gangguan terkait stres lainnya. Gejala seperti itu dapat berasal dari beragam sumber seperti beban kerja yang berlebihan, kurangnya peralatan proteksi diri, terpapar oleh beragam berita buruk mengenai COVID-19, dan kurangnya pertolongan dari tenaga kesehatan mental profesional (Yıldırım dkk., 2020).

Menurut data hasil rekap dari Satuan Tugas COVID-19 Jawa Timur mengenai jumlah tempat tidur di rumah sakit yang dijadikan rumah sakit rujukan di Jawa Timur, sejumlah rumah sakit memang sudah penuh, bahkan dari data salah satu rumah sakit rujukan menunjukkan bahwa per 4 Januari 2021 ruang isolasi baik yang memiliki ventilator maupun yang biasa atau tidak memiliki ventilator sudah penuh. Sedangkan ruangan ICU di Rumah Sakit Adi Husada Undaan Surabaya sudah penuh 100\%. Kondisi yang terjadi di Rumah Sakit Angkatan Laut dr. Ramelan Surabaya pun juga begitu, seperti dikutip dari Humas RSAL dr. Ramelan Surabaya mengatakan bahwa ruang ICU sudah penuh, namun masih bisa menerima pasien terinfeksi COVID-19 di IGD, namun jika ruangan sudah penuh maka terpaksa untuk mengedukasi pasien agar ke rumah sakit lainnya. Karenanya Pemerintah Kota Surabaya menambah rumah sakit dengan membangun rumah sakit darurat COVID-19 di perbatasan Kota Surabaya.

Menurut Dinas Penanaman Modal \& Pelayanan Terpadu Satu Pintu atau DPM \& PTSP Kota Surabaya seperti dikutip dari laman web nya mengatakan bahwa kapasitas tempat tidurnya sebanyak 105 unit yang mungkin bisa bertambah hingga 186 jika dibutuhkan, dan 8 ICU yang juga bisa bertambah hingga 16 ICU. Rumah sakit ini tepatnya berada di kompleks Mal City of Tomorrow (Cito) Surabaya. 
Tenaga kesehatan rentan terpapar oleh berbagai macam penyakit menular, termasuk yang ditularkan melalui transmisi darah, atau cairan tubuh lainnya. Penelitian menunjukkan bahwa kelompok tenaga kesehatan yang melakukan kontak secara langsung dengan pasien memiliki risiko yang sangat tinggi untuk terpapar virus. Perawat secara khusus sangat rentan terhadap banyak bahaya yang berhubungan dengan pekerjaan, dan mengalami tekanan emosional yang cukup besar dalam hubungannya dengan pekerjaan mereka. Hal ini sangat penting terutama selama masa pandemi penyakit menular dalam skala global, dan hal ini dapat menyebabkan stres dan burnout diantara para tenaga kesehatan (Talaee dkk., 2020). Mitigasi IDI menyebutkan, dari residen (calon dokter spesialis) yang diterjunkan, 1,267 orang positif COVID-19 per 19 Oktober. Dalam suasana seperti itu pun tenaga kesehatan masih menghadapi kejadian perampasan jenazah pasien positif atau yang diduga COVID-19, rumah sakit diserbu, tenaga kesehatan dimaki dan diusir (Santoso, 2020).

Burnout terjadi karena beragam alasan, termasuk tekanan yang tinggi di tempat kerja, kurangnya bantuan, work-life balance yang buruk, atau kurangnya kontrol atas diri sendiri, terlibat konflik, atau kewalahan dengan pekerjaannya. Tidak mengejutkan penelitian menunjukkan bahwa saat empati atau burnout meningkat, salah satunya menurun, mereka berhubungan secara negatif terhadap satu sama lain (Ridge, 2020).

Penelitian yang baru-baru ini dilakukan di Cina dari 29 Januari 2020 hingga 3 Februari 2020 untuk mengukur kesehatan mental dari dokter dan perawat menemukan bahwa para subjek menunjukkan prevalensi atas kecemasan, depresi, dan insomnia. Lebih jauh lagi penelitian yang dilakukan di Singapura dari 19 Februari 2020 hingga 13 Maret 2020, menemukan bahwa terjadi peningkatan tekanan psikologis, kecemasan, dan depresi diantara tenaga kesehatan selama pandemi COVID-19 (Elhadi dkk., 2020). Pandemi menimbulkan beban psikologis yang sangat besar pada tenaga kesehatan disebabkan karena stres di tempat kerja dan ketakutan yang dirasakan (Tan dkk., 2020).

Tenaga kesehatan seringkali rentan terhadap burnout, dengan tingkat burnout paling tinggi adalah berada pada tenaga kesehatan yang bekerja di lingkungan UGD dan ICU, dimana mereka terekspos oleh stres yang sangat tinggi terkait pekerjaan. Faktor-faktor yang diketahui berkontribusi pada risiko tinggi dari burnout adalah perawatan intensif untuk pasien, tingkat kematian yang tinggi, dan kondisi pekerjaan yang tidak sesuai dalam hal beban kerja yang terlalu tinggi, dan kurangnya waktu untuk memenuhi kebutuhan pasien secara memadai, karenanya tenaga kesehatan mengalami tingkat stres diatas batas kapasitas mereka, yang akhirnya menyebabkan burnout (Talaee dkk., 2020).

Dalam salah satu artikel yang dipublikasikan oleh Humas Fakultas Kedokteran Universitas Indonesia mengatakan bahwa sudah lebih dari 100 dokter, dan tenaga medis lain yang meninggal dunia akibat terinfeksi oleh COVID-19 saat melakukan pekerjaannya sebagai pelayan kesehatan. Pada penelitian yang dilakukan oleh tim peneliti dari Program Studi Magister Kedokteran Kerja Fakultas Kedokteran Universitas Indonesia menunjukkan hasil bahwa 83\% tenaga kesehatan di Indonesia telah mengalami burnout mulai dari derajat sedang hingga berat, dan ini sudah berpotensi mengganggu kualitas hidup dan produktivitas kerja dalam pelayanan kesehatan. Dalam penelitian ini juga ditemukan bahwa dokter umum di Indonesia yang berhadapan langsung dengan pasien selama masa pandemi COVID-19 menunjukkan risiko 2 kali lebih besar untuk mengalami burnout (Humas FKUI, 2020).

“Tingginya risiko menderita burnout syndrome akibat pajanan stres yang luar biasa berat di fasilitas kesehatan selama pandemik ini dapat mengakibatkan efek jangka panjang terhadap kualitas pelayanan medis karena para tenaga kesehatan ini bisa merasa depresi, kelelahan ekstrim bahkan merasa kurang kompeten dalam menjalankan tugas, dan ini tentu berdampak kurang baik bagi upaya kita memerangi COVID-19," menurut ketua tim peneliti dr. Dewi. Temuan lain dari penelitian ini adalah $41 \%$ tenaga 
kesehatan mengalami kelelahan emosi mulai dari derajat sedang hingga berat, 22\% menunjukkan hilangnya empati mulai dari derajat sedang hingga berat. Dokter baik yang umum maupun spesialis yang menangani pasien COVID-19 mengalami risiko 2 kali lebih besar untuk merasakan kelelahan emosi, dan kehilangan empati, dibanding yang tidak menangani pasien COVID-19.

Konsekuensi dari burnout tidak terbatas hanya pada permasalahan personal dari tenaga kesehatan yang mengalami burnout, tapi juga berdampak pada penanganan pasien. Banyak penelitian telah menunjukkan bahwa burnout pada tenaga kesehatan merugikan pasien dalam perawatannya, misalnya jumlah kesalahan medis yang dilakukan oleh seorang ahli bedah berkorelasi dengan tingkat burnout dari si ahli bedah, dan mungkin juga terlibat dalam gugatan malapraktik. Diantara para perawat, tingkat burnout yang tinggi berhubungan dengan makin tinggi tingkat kematian dari pasien maupun perawat (Reith, 2018). Di Indonesia sendiri hal ini dibuktikan dengan pernyataan Tim Mitigasi Pengurus Besar Ikatan Dokter Indonesia (IDI) yang menyebutkan bahwa sebanyak 647 tenaga kesehatan di Indonesia gugur karena terpapar virus corona, dengan rincian 289 dokter, 27 dokter gigi, 221 perawat, 84 bidan, 11 apoteker, dan 15 tenaga lab medik (CNN Indonesia, 2021). Tingginya tingkat burnout pada dokter juga berkorelasi dengan tingkat kepuasan pasien yang rendah.

Pada tingkat institusi burnout dapat menyebabkan peningkatan keluarnya tenaga kesehatan dari pekerjaannya, begitu juga dengan dokter dan perawat. Ini juga berhubungan dengan berkurangnya efisiensi di tempat kerja. Akibatnya, kelelahan dapat memperparah keadaan kekurangan dokter dan perawat. Intinya burnout memberikan efek secara negatif kepada tenaga kesehatan dan pasien. Kondisi yang sangat stres menuju pada pengambilan keputusan yang buruk, yang akan menyebabkan penanganan pasien pun juga akan menjadi buruk (Clark, 2019).

Pada salah satu penelitian yang membahas tentang faktor yang memengaruhi terjadinya burnout dari Ghent University mengelompokkan faktor penyebab burnout menjadi 2, yaitu faktor internal dan faktor eksternal, pada faktor internal ada ekspektasi yang tinggi terhadap diri sendiri atau idealis, perfeksionis, sangat butuh pengakuan, selalu ingin menyenangkan orang lain, menahan kebutuhan diri sendiri, merasa tidak tergantikan, bekerja hanya sebagai aktivitas yang berarti, bekerja hanya sebagai pengganti kehidupan sosial, dan berlebih-lebihan dalam menghadapi tantangan.

Sedangkan faktor eksternal penyebab burnout adalah tuntutan yang tinggi dalam pekerjaan, adanya permasalahan dalam kolaborasi dan kepemimpinan, instruksi yang kontradiktif, tekanan waktu, perundungan atau lingkungan pekerjaan yang buruk, kurangnya kebebasan dalam membuat keputusan, kurangnya pengaruh organisasi, sedikitnya peluang untuk berpartisipasi, permasalahan hierarki, komunikasi internal yang buruk, kendala administrasi, tekanan dari atasan, meningkatnya tanggung jawab, organisasi dengan kerja yang buruk, kurangnya sumber daya seperti kurang orang atau kekurangan dana, permasalahan pada aturan dan struktur institusi, kurangnya keselarasan tentang peran, kurangnya timbal balik positif, jeleknya kerjasama tim, tidak adanya dukungan sosial, dan perasaan akan kurangnya kesempatan atas promosi (De Hert, 2020).

Secara umum, munculnya pandemi berkontribusi pada atmosfer ketakutan yang perlu secara psikologis diteliti secara komprehensif untuk memahami kemungkinan dampak negatif pada kesehatan mental individu, dan produktivitasnya. Selama menyebarnya epidemic SARS pada tahun 2003 dan pandemi H1N1 di tahun 2009, peneliti mengevaluasi stres psikologis pada tenaga kesehatan melalui beberapa metode, dan mengobservasi tingginya tingkat stres diantara tenaga kesehatan (Talaee dkk., 2020).

Masa pandemi memperburuk risiko yang sudah ada, dan bahkan memunculkan risiko yang baru, termasuk risiko terpapar patogen, jam kerja yang panjang, jumlah dan tingkat keparahan pasien yang 
meningkat, pengambilan keputusan yang susah, permasalahan psikologis, kelelahan, dan kekhawatiran jika tenaga kesehatan bisa menjadi pembawa virus terhadap keluarganya. Risiko-risiko ini bisa membahayakan mental, fisik, emosional, dan kesejahteraan sosial dari para tenaga kesehatan, dan ini juga berdampak pada proses perawatan pasien. Di waktu yang bersamaan determinan yang signifikan dari burnout terkait personal maupun pekerjaan adalah permasalahan kesehatan, dan partisipasi langsung dalam diagnosis, dan perawatan pasien COVID-19 (Duarte dkk., 2020). Pada penelitian yang dilakukan dengan sampel dokter di Mesir menunjukkan bahwa ketakutan terhadap COVID-19 secara positif berkorelasi dengan kecemasan, depresi, dan burnout (Abdelghani, dkk., 2020).

Tujuan dari penelitian ini adalah untuk menganalisis pengaruh fear of covid-19 terhadap burnout, dengan resiliensi sebagai variabel mediator pada tenaga kesehatan. Penelitian ini diharapkan mampu memberikan pengetahuan mengenai dampak dari fear of COVID-19 terhadap burnout dengan resiliensi sebagai variabel mediatornya, sehingga pemerintah atau pihak rumah sakit dapat menjaga tenaga kesehatannya agar tidak menjadi burnout. Hipotesis penelitian ini adalah (1) Tidak terdapat pengaruh fear of COVID-19 terhadap burnout dengan mediasi resiliensi pada tenaga kesehatan; (2) Terdapat pengaruh fear of COVID-19 terhadap burnout dengan mediasi resiliensi pada tenaga kesehatan.

\section{Fear of COVID-19}

Fear of COVID-19 adalah perasaan ketakutan terhadap COVID-19. Ketakutan adalah emosi adaptif yang berfungsi untuk memobilisasi energi untuk menghadapi potensi ancaman (Mertens dkk., 2020). COVID19 adalah penyakit menular yang disebabkan oleh virus corona yang baru ditemukan. Kebanyakan orang yang terinfeksi virus COVID-19 akan mengalami penyakit pernapasan ringan hingga sedang dan sembuh tanpa memerlukan perawatan khusus. Para orang tua, dan yang memiliki masalah medis seperti penyakit kardiovaskular, diabetes, penyakit pernapasan kronis, dan kanker lebih mungkin mengembangkan penyakit serius (WHO, 2021).

\section{Resiliensi}

Resiliensi adalah kemampuan untuk dapat melalui keadaan dengan gangguan dan stres yang ekstrem. Orang yang resilien, yang memiliki kemampuan untuk bertahan hidup dan mempertahankan interaksi mereka dengan lingkungan terlepas dari semua permasalahan lingkungan adalah orang-orang yang biasanya tidak frustasi dalam menghadapi peristiwa-peristiwa yang membuat stres, sebaliknya, dapat dengan cepat pulih, bahkan lebih kuat dan mampu menyingkirkan masalah dan kerugian dari permasalahan lingkungan (Karataş \& Tagay, 2021).

\section{Burnout}

Burnout adalah kondisi kelelahan fisik, emosional, dan mental yang dihasilkan dari situasi kerja yang sangat menuntut secara emosional dalam jangka panjang. Burnout dialami oleh orang dengan tingkat kelelahan fisik, emosional, dan psikologis yang tinggi (Duarte dkk., 2020). Burnout juga dapat mengarah pada berkurangnya produktivitas dalam pekerjaan, ini adalah hasil dari usaha yang berlebihan dalam tempat kerja dengan kesempatan untuk recovery yang terbatas (Talaee dkk., 2020).

\section{Desain Penelitian}

\section{E T O D E}

Tipe penelitian yang digunakan dalam penelitian ini adalah tipe penelitian kuantitatif dengan menggunakan rancangan survei untuk mengumpulkan data. Penelitian yang menggunakan metode kuantitatif menekankan analisisnya pada data-data kuantitatif (angka) yang dikumpulkan melalui 
prosedur pengukuran dan diolah dengan metoda analisis statistika(Azwar, 2014). Penelitian kuantitatif merupakan metode untuk menguji teori tertentu dengan cara meneliti hubungan antar variabel (Creswell, 2010). Dalam rancangan survei, peneliti mendeskripsikan kecenderungan, perilaku, atau opini dari suatu populasi secara kuantitatif dengan meneliti sampel populasi tersebut (Creswell, 2010).

\section{Partisipan}

Partisipan dalam penelitian ini adalah tenaga kesehatan. Teknik sampling yang digunakan dalam penelitian ini adalah simple random sampling, dengan seluruh sampel mungkin menjadi partisipan penelitian. Sebelum melanjutkan untuk mengisi kuesioner penelitian, partisipan terlebih dahulu diminta untuk mengisi informed consent yang berisi kesediaan untuk menjadi partisipan penelitian. Dalam penelitian ini terdapat 87 partisipan $\left(\mathrm{M}_{\text {usia }}=30,54 ; \mathrm{SD}_{\text {usia }}=8,61 ; 28,74\right.$ persen laki-laki; 71,26 persen perempuan).

\section{Pengukuran}

Pada penelitian ini digunakan 3 alat ukur, yaitu Fear of COVID-19 versi Indonesia berisikan 7 aitem dengan skala likert dari 1 hingga 5, dengan koefisien reliabilitas $(\alpha=.83)$. Alat ukur kedua adalah Brief Resilience Scale berisikan 6 aitem dengan 3 aitem favorable, dan 3 aitem unfavorable, dengan skala likert dari 1 hingga 5, koefisien reliabilitas $(\alpha=.86)$. Alat ukur ketiga adalah Maslach Burnout Inventory yang berisikan 22 aitem, dengan 9 aitem untuk mengukur kelelahan emosional, 8 item untuk mengukur depersonalisasi, dan 5 item untuk mengukur pencapaian diri, dengan skala likert dari 1 hingga 5 , koefisien reliabilitas $(\alpha=.90)$.

\section{Analisis Data}

Teknik analisis data yang digunakan pada penelitian ini adalah dengan menggunakan uji asumsi, yaitu uji normalitas untuk mengetahui sebaran data termasuk normal atau tidak, dan uji linearitas yang digunakan untuk mengetahui kecenderungan hubungan antar variabel penelitian, lalu untuk uji mediasi menggunakan analisis mediasi standar pada program Jamovi.

\section{HAS IL P EN ELIT IAN}

Hasil uji analisis deskriptif menunjukkan nilai rata-rata dari variabel fear of COVID-19 adalah 18,8, sedangkan untuk resiliensi adalah 3,10, dan untuk burnout adalah 68,5. Nilai tertinggi dari variabel fear of COVID-19 adalah 31 dengan nilai terendah adalah 7, sedangkan untuk nilai tertinggi pada variabel resiliensi adalah 4,67 dengan nilai terendah adalah 2, dan nilai tertinggi untuk variabel burnout adalah 135 dengan nilai terendah adalah 33. Sedangkan untuk uji normalitas didapatkan hasil bahwa ketiga variabel berdistribusi normal, yaitu skewness dan kurtosis tidak melebihi \pm 2 . Hasil dari uji linearitas menunjukkan bahwa hubungan fear of COVID-19 dengan burnout, fear of COVID-19 dengan resiliensi, dan resiliensi dengan burnout adalah linear. Uji korelasi menunjukkan hasil bahwa burnout berkorelasi negatif $(r(87)=-0,50 ; p<0.001)$ dengan resiliensi, sedangkan burnout berkorelasi positif $(r(87)=0,50$; $p<0.001)$ dengan fear of COVID-19, lalu untuk resiliensi berkorelasi negatif $(r(87)=-0,53 ; p<0.001)$ dengan fear of COVID-19.

Hasil uji mediasi menunjukkan nilai estimate untuk indirect effect adalah 0,620, ini menunjukkan bahwa terdapat efek mediasi, sedangkan nilai estimate untuk direct effect adalah 1,18. Nilai untuk total effect adalah 1,79 yang mana lebih besar dari indirect effect dan bernilai signifikan yang menjadikan resiliensi menjadi mediasi parsial dengan mampu menerangkan 34,5\% hubungan antara fear of COVID-19 dengan burnout. Lalu untuk koefisien jalur menunjukkan pengaruh fear of COVID-19 terhadap resiliensi jika 
dibulatkan adalah -0,06 yang berarti setiap kenaikan nilai fear of COVID-19 mengakibatkan penurunan nilai resiliensi, pengaruh resiliensi terhadap burnout pun juga menunjukkan hasil $-11,30$ yang berarti setiap kenaikan resiliensi mengakibatkan penurunan nilai burnout, dan pengaruh fear of COVID-19 terhadap burnout jika dibulatkan adalah 1,18 yang berarti setiap kenaikan nilai fear of COVID-19 maka nilai burnout pun juga akan naik. Seluruh jalur bernilai signifikan menandakan setiap variabel memiliki pengaruh yang signifikan dengan variabel lain, yaitu lebih kecil dari 0,05.

\section{I S K U S I}

Hasil yang didapatkan dari pengujian ini adalah Ho ditolak, dan Ha diterima, yang berarti terdapat pengaruh fear of COVID-19 terhadap burnout dengan mediasi resiliensi pada tenaga kesehatan. Resiliensi memediasi pengaruh antara fear of COVID-19 terhadap burnout secara parsial. Dari pengujian ini juga didapatkan hasil bahwa pengaruh fear of COVID-19 terhadap resiliensi adalah negatif dimana setiap nilai fear of COVID-19 naik maka nilai resiliensi menurun, sedangkan pengaruh fear of COVID-19 terhadap burnout adalah positif dimana setiap nilai fear of COVID-19 mengalami kenaikan maka nilai burnout pun juga ikut naik, dan pengaruh resiliensi terhadap burnout adalah negatif dimana setiap kenaikan nilai resiliensi maka nilai burnout akan menurun. Fear of COVID-19 atau ketakutan terhadap COVID-19 adalah sebuah emosi yang tidak menyenangkan didampingi dengan tingkat emotive avoidance yang berlebihan pada COVID-19 (Ylldırım dkk., 2020). Pada salah satu penelitian yang meneliti tentang faktor yang berhubungan dengan fear of COVID-19 menyatakan bahwa faktor paling penting yang berhubungan dengan fear of COVID-19 adalah terkena infeksi, karantina, tidak mendapatkan perawatan medis, kehilangan nyawa, dan menginfeksi anggota keluarga (Kumar dkk., 2020).

Pada penelitian ini menunjukkan hasil bahwa fear of COVID-19 berkorelasi negatif dan signifikan terhadap resiliensi, hasil ini sesuai dengan hasil pada penelitian-penelitian sebelumnya yang juga menyebutkan bahwa fear of COVID-19 berkorelasi negatif dan signifikan terhadap resiliensi. Fear of COVID-19 secara negatif dan signifikan mampu memprediksi resiliensi (Karataş \& Tagay, 2021). Pada penelitian lain menyebutkan bahwa fear of COVID-19 memiliki hubungan negatif dengan resiliensi, dan menemukan bahwa fear of COVID-19 mengandung risiko untuk resiliensi pada tenaga kesehatan (Seçer dkk., 2020).

Pada penelitian ini juga menunjukkan hasil bahwa fear of COVID-19 berkorelasi positif dan signifikan terhadap burnout, dimana jika nilai fear of COVID-19 naik, maka nilai burnout pun juga akan naik, ini sejalan dengan hasil pada salah satu penelitian yang menyatakan bahwa fear of COVID-19 berkorelasi secara positif dan signifikan terhadap burnout (Abdelghani dkk., 2020). Hasil pada penelitian ini juga menunjukkan bahwa resiliensi berkorelasi negatif dan signifikan terhadap burnout, dimana jika nilai resiliensi meningkat maka nilai burnout akan menurun, hal ini sejalan dengan hasil pada salah satu penelitian yang menyatakan bahwa resiliensi memiliki korelasi yang kuat dan signifikan terhadap burnout (Kareepadath Rajan, 2013).

Hasil penelitian ini sejalan dengan referensi yang digunakan oleh peneliti dalam membuat penelitian ini, hal ini bisa jadi karena memang selama masa pandemi tenaga kesehatan memang merasa takut akan COVID-19, hal ini wajar karena para tenaga kesehatan sangat sadar akan dampak dari terinfeksi COVID19 mulai dari dampaknya terhadap orang yang terinfeksi, hingga dampak yang bisa ditimbulkan kepada orang-orang disekitar orang yang terinfeksi, lalu untuk burnout yang dirasakan oleh tenaga kesehatan juga selama masa pandemi tentu secara umum meningkat, karena permasalahan kesehatan yang sangat besar selama masa pandemi membuat tenaga kesehatan secara umum kewalahan dalam menghadapi 
jumlah pasien yang meningkat drastis, terutama bagi tenaga kesehatan yang bekerja secara langsung dengan pasien terinfeksi COVID-19, pada beberapa jenis profesi tenaga kesehatan memang tidak begitu merasakan burnout karena mereka membatasi pasien yang akan ditangani, seperti jika dalam kondisi darurat, selama masih belum kondisi darurat maka konsultasi bisa dilakukan tanpa tatap muka secara langsung, ada juga tenaga kesehatan yang sengaja untuk tidak menangani pasien terlebih dahulu selama masa pandemi, karena takut tertular.

\section{S I M P U L A N}

Setelah melakukan analisis data, pada penelitian ini ditemukan hasil bahwa terdapat korelasi positif dan signifikan dari fear of COVID-19 terhadap burnout, dimana setiap terjadi kenaikan nilai fear of COVID-19 maka terjadi kenaikan juga pada nilai burnout, sedangkan fear of COVID-19 memiliki korelasi negatif dan signifikan terhadap resiliensi, dimana setiap kenaikan nilai fear of COVID-19 terjadi penurunan nilai resiliensi, dan resiliensi memiliki korelasi negatif dan signifikan terhadap nilai burnout, dimana setiap terjadi kenaikan nilai resiliensi maka akan terjadi penurunan nilai burnout. Pada penelitian ini juga membuktikan bahwa variabel resiliensi memiliki peran yang memediasi pengaruh dari fear of COVID19 terhadap burnout secara parsial sebanyak 34,5\%.

\section{U C A P A N T E R I MAKASIH}

Terima kasih sebanyak-banyaknya kepada Allah SWT, keluarga, teman, seluruh partisipan penelitian, serta seluruh pihak yang tulus dan baik membantu saya, yang tidak bisa saya sebutkan satu-satu dan tidak akan pernah cukup saya memberikan rasa terima kasih.

\section{DEKLARASI POTENSI TERJADINYAKONFLIKKEPENTINGAN}

Fikri Hadyan Kusuma dan Herison Pandapotan Purba tidak bekerja, menjadi konsultan, memiliki saham, atau menerima dana dari perusahaan atau organisasi maupun yang mungkin akan mengambil untung dari diterbitkannya naskah ini.

\section{PUSTAKA ACUAN}

Abdelghani, M., El-Gohary, H. M., Fouad, E., \& Hassan, M. S. (2020). Addressing the relationship between perceived fear of COVID-19 virus infection and emergence of burnout symptoms in a sample of Egyptian physicians during COVID-19 pandemic: a cross-sectional study. Middle East Current Psychiatry, 27(1). https://doi.org/10.1186/s43045-020-00079-0

Azwar, S. (2014). Dasar-Dasar Psikometri. Yogyakarta: Pustaka Belajar.

Clark, M. (2019). The 5 Main Causes of Burnout in Healthcare. Retrieved from https://etactics.com/blog/burnout-in-healthcare-causes

CNN Indonesia. (2021). 647 Nakes RI Wafat karena Covid, Tertinggi Ketiga di Dunia. Retrieved from https://www.cnnindonesia.com/nasional/20210128101510-20-599386/647-nakes-ri-wafatkarena-covid-tertinggi-ketiga-di-dunia 
COVID-19. (2021). Data Sebaran COVID-19. Retrieved from covid19.go.id

Creswell, J. (2010). RESEARCH DESIGN Pendekatan Kualitatif, Kuantitatif, dan Mixed Edisi Ketiga. Yogyakarta: PUSTAKA PELAJAR.

De Hert, S. (2020). Burnout in healthcare workers: Prevalence, impact and preventative strategies. Local and Regional Anesthesia, 13, 171-183. https://doi.org/10.2147/LRA.S240564

Duarte, I., Teixeira, A., Castro, L., Marina, S., Ribeiro, C., Jácome, C., ... Serrão, C. (2020). Burnout among Portuguese healthcare workers during the COVID-19 pandemic. BMC Public Health, 20(1), 1-10. https://doi.org/10.1186/s12889-020-09980-z

Elhadi, M., Msherghi, A., Elgzairi, M., Alhashimi, A., Bouhuwaish, A., Biala, M., ... Zaid, A. (2020). Burnout Syndrome Among Hospital Healthcare Workers During the COVID-19 Pandemic and Civil War: A Cross-Sectional Study. Frontiers in Psychiatry, 11(December), 1-11. https://doi.org/10.3389/fpsyt.2020.579563

Humas FKUI. (2020). 83\% Tenaga Kesehatan Indonesia Mengalami Burnout Syndrome Derajat Sedang dan Berat Selama Masa Pandemi COVID-19. Retrieved from https://fk.ui.ac.id/berita/83-tenagakesehatan-indonesia-mengalami-burnout-syndrome-derajat-sedang-dan-berat-selama-masapandemi-covid-19.html

Karataş, Z., \& Tagay, Ö. (2021). The relationships between resilience of the adults affected by the covid pandemic in turkey and Covid-19 fear, meaning in life, life satisfaction, intolerance of uncertainty and hope. Personality and Individual Differences, 172(November 2020). https://doi.org/10.1016/j.paid.2020.110592

Kareepadath Rajan, S. (2013). the Effect of Resilience on Burnout Among the Bluecollared Employees in Metal Factories. EXCEL International Journal of Multidisciplinary Management Studies, 3(6), 48-55.

Kumar, J., Katto, M. S., Siddiqui, A. A., Sahito, B., Ahmed, B., Jamil, M., \& Ali, M. (2020). Predictive Factors Associated With Fear Faced by Healthcare Workers During COVID-19 Pandemic: A QuestionnaireBased Study. Cureus, (June). https://doi.org/10.7759/cureus.9741

Labrague, L. J., \& de los Santos, J. A. A. (2020). Fear of COVID-19, psychological distress, work satisfaction and turnover intention among frontline nurses. Journal of Nursing Management, 1-18. https://doi.org/10.1111/jonm.13168

Mertens, G., Gerritsen, L., Duijndam, S., Salemink, E., \& Engelhard, I. M. (2020). Fear of the coronavirus (COVID-19): Predictors in an online study conducted in March 2020. Journal of Anxiety Disorders, 74(June), 102258. https://doi.org/10.1016/j.janxdis.2020.102258

Reith, T. P. (2018). Burnout in United States Healthcare Professionals: A Narrative Review. Cureus, 10(12). https://doi.org/10.7759/cureus.3681

Ridge, D. (2020). Burnout in healthcare staff is common - and can make empathising with patients difficult. Retrieved from https://theconversation.com/burnout-in-healthcare-staff-is-commonand-can-make-empathising-with-patients-difficult-145862\#: :text=Burnout and empathy,quality 
patient care more difficult.

Santoso, D. (2020). Suara Dokter yang Kian Sayup dalam Kebijakan Pandemi. Retrieved from https://www.kompas.id/baca/opini/2020/10/30/suara-dokter-yang-kian-sayup-dalamkebijakan-pandemi/

Seçer, I., Ulaş, S., \& Karaman-Özlü, Z. (2020). The Effect of the Fear of COVID-19 on Healthcare Professionals' Psychological Adjustment Skills: Mediating Role of Experiential Avoidance and Psychological Resilience. Frontiers in Psychology, 11(October), 1-10. https://doi.org/10.3389/fpsyg.2020.561536

Talaee, N., Varahram, M., Jamaati, H., Salimi, A., Attarchi, M., Kazempour dizaji, M., ... Seyedmehdi, S. M. (2020). Stress and burnout in health care workers during COVID-19 pandemic: validation of a questionnaire. Journal of Public Health (Germany). https://doi.org/10.1007/s10389-020-01313-z

Tan, B. Y. Q., Kanneganti, A., Lim, L. J. H., Tan, M., Chua, Y. X., Tan, L., ... Ooi, S. B. S. (2020). Burnout and Associated Factors Among Health Care Workers in Singapore During the COVID-19 Pandemic. Journal of the American Medical Directors Association, 21(12), 1751-1758.e5. https://doi.org/10.1016/j.jamda.2020.09.035

WHO. (2021). WHO Coronavirus Disease (COVID-19) Dashboard. Retrieved from https://covid19.who.int/

Yıldırım, M., Arslan, G., \& Özaslan, A. (2020). Perceived Risk and Mental Health Problems among Healthcare Professionals during COVID-19 Pandemic: Exploring the Mediating Effects of Resilience and Coronavirus Fear. International Journal of Mental Health and Addiction. https://doi.org/10.1007/s11469-020-00424-8 